Check for updates

Cite this: RSC Adv., 2017, 7, 49361

Received 3rd July 2017

Accepted 16th September 2017

DOI: 10.1039/c7ra07315a

rsc.li/rsc-advances

\title{
Green aqueous biphasic systems containing deep eutectic solvents and sodium salts for the extraction of protein $\dagger$
}

\author{
Jingyu Pang, ${ }^{a}$ Xiaofang Sha, ${ }^{b}$ Yanhong Chao, (D)*b Guangying Chen, ${ }^{\mathrm{C}}$ Changri Han, ${ }^{\mathrm{c}}$ \\ Wenshuai Zhu, (D) d Huaming Li ${ }^{d}$ and Qi Zhang*ad
}

\begin{abstract}
Deep eutectic solvents (DESs), a new type of green solvents, were applied for the extraction of proteins with aqueous biphasic systems (ABSs) in this study. The structures of the prepared DES were confirmed by FT-IR and ${ }^{1} \mathrm{H}$ NMR. The DES-salt $\left(\mathrm{NaH}_{2} \mathrm{PO}_{4} / \mathrm{Na}_{2} \mathrm{CO}_{3} / \mathrm{Na}_{3} \mathrm{C}_{6} \mathrm{H}_{5} \mathrm{O}_{7}\right)$-based $A B S s$ were established and applied to extract the bovine serum albumin and papain. $\mathrm{DES}-\mathrm{Na}_{2} \mathrm{CO}_{3} \mathrm{ABS}$ was selected as the suitable extraction system. Single-factor experiments were investigated to achieve complete extraction by properly tailoring the concentration of different compositions (e.g. proteins, $\mathrm{Na}_{2} \mathrm{CO}_{3}, \mathrm{DES}$ ), the temperature and $\mathrm{pH}$ values. The experimental results indicated that the extraction efficiency could reach up to $95.16 \%$ for bovine serum albumin and $90.95 \%$ for papain under the optimum conditions. UV-vis spectra, fluorescence spectra and CD spectra were investigated to confirm that the conformation of bovine serum albumin did not change after extraction. The transmission electron microscopy (TEM) was used to explore the mechanism of the extraction. All of these results indicated that DES-based ABSs may provide a new possibility for the separation of proteins.
\end{abstract}

\section{Introduction}

Aqueous biphasic systems (ABSs), pioneered by Albertson, ${ }^{1}$ are formed by two immiscible water-rich phases based on polymerpolymer interaction under a critical concentration and temperature. It can be proposed as a possible alternative for protein extraction due to their advantages such as operational cost, tunable composition, technological simplicity and mild conditions. ${ }^{2}$ Owing to their water-rich environment, ABSs process fulfill the requisites regarding green chemistry principles and gain potential for the research of industrial applications..$^{3-5}$ Therefore, ABSs have been proved to be a versatile and significant technique for the purification and separation of diverse targets, namely carbon nanotubes, ${ }^{6-8}$ alkaloids, ${ }^{9,10}$ antibiotics, ${ }^{11-13}$ amino acids ${ }^{14-16}$ and proteins. ${ }^{17-19}$ Proteins are essential units of organisms, and they play important roles in cell metabolism. Therefore, the study of extraction and separation of proteins is of great significance.

${ }^{a}$ School of Food and Biological Engineering, Jiangsu University, Zhenjiang 212013, P. R. China.E-mail: qzhang@ujs.edu.cn

${ }^{b}$ School of Pharmacy, Jiangsu University, Zhenjiang 212013, P. R. China. E-mail: chaoyh@ujs.edu.cn

'Key Laboratory of Tropical Medicinal Plant Chemistry of Education, Hainan Normal University, Haikou 571158, P. R. China

${ }^{d}$ School of Chemistry and Chemical Engineering, Jiangsu University, Zhenjiang 212013, P. R. China

$\dagger$ Electronic supplementary information (ESI) available. See DOI: 10.1039/c7ra07315a
The most commonly used ABSs for the extraction of proteins are composed of two polymers, particularly ionic liquids (IL). In 2003, the so-called green solvents have been reported to displace organic compounds from organic phase and have attracted much attention in the formation of ABS due to their negligible volatility, non-flammability, excellent thermal and chemical stabilities, large liquid range and wide structural diversity. ${ }^{20}$ However, the synthesis process of common IL are complex and expensive; also they are difficult to purify. In addition, several of these IL (e.g. imidazolium- and pyridiniumbased IL) are highly toxic and poorly biodegradable. ${ }^{21-23}$ These disadvantages limit their development and large-scale industrial applications. Thus, the research for a cheaper and greener substitute while taking advantage of their benefits is still an imperative issue.

Deep eutectic solvents (DESs) are classified as a new type of IL or IL analog because of their similarity in physical properties with $\mathrm{IL}^{24,25}$ It is a eutectic mixture synthesized by mixing hydrogen bond acceptors (e.g. quaternary ammonium, phosphonium salts, etc.) and hydrogen bond donors (e.g. amides, alcohols, acids, etc.). ${ }^{26,27}$ Choline chloride ( $\mathrm{ChCl}$ ), one of the most widespread quaternary ammonium salts, is often utilized to synthesize DESs. ${ }^{26}$ Indeed, ChCl-based DESs not only share the common advantages such as negligible volatility, nonflammability, excellent thermal and chemical stabilities but also show excellent biodegradability and low toxicity. Owing to the outstanding properties, scientific interest for ChCl-based DESs have increased in the past few years, ${ }^{28,29}$ with 
applications in many fields such as desulfurization, ${ }^{30-32}$ biomass, ${ }^{33,34}$ extraction ${ }^{35-37}$ and electrochemistry. ${ }^{38,39}$ Based on these advantages, ChCl-based DESs have emerged as promising solvents to be used in ABSs. Xu et al. synthesized four types of ChCl-polyol-based DESs and applied them to extract bovine serum albumin with ABSs. ${ }^{\mathbf{4 0}}$ Li et al. explored ChCl-based DESs (ChCl-urea, ChCl-methylurea, etc.) and investigated the extraction efficiency of bovine serum albumin. ${ }^{18}$ Some researchers have already focused on the DES-based ABSs; yet there is plenty of room for development.

In this study, ChCl-based DESs were prepared and characterized and converted to ABSs using salt solutions (e.g. $\mathrm{NaH}_{2} \mathrm{PO}_{4}, \mathrm{Na}_{2} \mathrm{CO}_{3}$ and $\left.\mathrm{Na}_{3} \mathrm{C}_{6} \mathrm{H}_{5} \mathrm{O}_{7}\right)$. Among them, DES- $\mathrm{Na}_{2} \mathrm{CO}_{3}$ was selected to investigate the extraction of protein (bovine serum albumin and papain) and identify the optimal conditions. UV-vis spectra, fluorescence spectra, CD spectra and TEM were used to study the mechanisms during the extraction process.

\section{Experimental}

\section{Reagents and apparatus}

Polyethylene glycol 2000 (PEG), choline chloride (ChCl, purity 98.0-101.0\%), $\mathrm{NaH}_{2} \mathrm{PO}_{4}$ (purity $\geq 99.0 \%$ ), $\mathrm{Na}_{2} \mathrm{CO}_{3}$ (purity $\geq$ 99.8\%), $\mathrm{Na}_{3} \mathrm{C}_{6} \mathrm{H}_{5} \mathrm{O}_{7}$ (purity $\geq 99.0 \%$ ), bovine serum albumin and papain were all purchased from Sinopharm Chemical Reagent Co., Ltd. PEG and $\mathrm{ChCl}$ were dried under vacuum before use.

Materials were dried in the DZF-6051 vacuum drying oven (Shanghai, China). Deep eutectic solvents were heated in the IKA RET basic safety control-type magnetic stirrer. The H1650 Cence high-speed centrifuge was utilized to speed up the phase separation. Ultraviolet spectrum of the protein solution was measured using the UV2450 UV-vis spectrophotometer (Shimadzu, Japan). Infrared spectrum of DESs was recorded on the Spectrum One FT-IR spectrometer (Nicolet Nexus 470). The secondary structure of protein was determined using the Mos500 circular dichroism (CD) spectrometer. The microstructure of the sample was examined using the JEM-3010 transmission electron microscope (TEM, Hitachi H-700, Japan).

\section{Preparation and characterization of DES}

In this study, ChCl-based DES was prepared by stirring two compounds, $\mathrm{ChCl}$ and PEG (molar ratio of $20: 1$, according to the freezing point), at $110{ }^{\circ} \mathrm{C}$ until a homogeneous colourless liquid was formed. Detailed data are summarized in Tables S1 and S2. $\uparrow$ This ChCl-PEG was abbreviated as DES. The structures were confirmed by FT-IR and ${ }^{1} \mathrm{H}$ NMR.

\section{Phase diagrams}

Binodal curves, which illustrate the binding between the homogeneous and biphasic regions, were determined at atmospheric pressure and $298 \mathrm{~K}$ by the cloud point method. ${ }^{\mathbf{4 1}}$ First, a certain amount of DES was weighed in a colorimetric tube. Following this, the saturated salt solutions were added dropwise until detecting a cloudy solution. Then ultrapure water was added dropwise until a clear, limpid solution corresponding to the monophasic regime was formed. The mass was recorded after each addition and the above process was repeated until sufficient data were obtained to determine the phase diagram. The entire procedure was carried out under constant stirring and the curves were determined gravimetrically within $\pm 10^{-4} \mathrm{~g}$.

\section{Extraction of proteins: bovine serum albumin and papain}

The extraction of proteins using DES-based ABSs was carried out in graduated glass centrifuge tubes containing appropriate amounts of each salt, DES and an aqueous solution containing protein. After completely mixing all the components to a given mixture composition, each system was centrifuged at $2000 \mathrm{rpm}$ for $10 \mathrm{~min}$ and then, each tube was placed in a thermostatic bath at $298 \mathrm{~K}$ for at least $30 \mathrm{~min}$. Then the two phases became clear and transparent, the volume of each phase was measured, and the concentration of the protein in both phases was detected using a UV-vis spectrophotometer. The linear calibration curves for bovine serum albumin and papain obtained in the range of $0-1 \mathrm{mg} \mathrm{mL}^{-1}$ were $A=0.6318 C+0.0022\left(R^{2}=1, \lambda=\right.$ $278 \mathrm{~nm})$ and $A=0.2877 C-0.0012\left(R^{2}=0.9998, \lambda=278 \mathrm{~nm}\right)$, respectively, where $C$ is the concentration of proteins $\left(\mathrm{g} \mathrm{L}^{-1}\right)$ and $A$ is the UV absorbance.

The extraction efficiency $(E)$ was calculated using the following eqn (1):

$$
E=\frac{C_{\mathrm{t}} V_{\mathrm{t}}}{C_{\mathrm{t}} V_{\mathrm{t}}+C_{\mathrm{b}} V_{\mathrm{b}}}
$$

where $C_{\mathrm{t}}$ and $C_{\mathrm{b}}$ are the concentrations of the proteins in the DES-rich top phase and salt-rich bottom phase, respectively. $V_{\mathrm{t}}$ and $V_{\mathrm{b}}$ represent the volume of the top phase and the bottom phase, respectively.

\section{Results and discussion}

\section{Characterization of DES}

FT-IR spectra of the ChCl, PEG and DES are shown in Fig. 1(a). The band at $3016 \mathrm{~cm}^{-1}$ corresponds to the $-\mathrm{CH}_{3}$ stretching modes, which were clearly found in both $\mathrm{ChCl}$ and DES; the absorption bands at $960 \mathrm{~cm}^{-1}$ and $950 \mathrm{~cm}^{-1}$ can be attributed to the $\mathrm{C}-\mathrm{O}$ stretching vibration of PEG and DES. Red-shift of the peaks in DES indicated that a more stable $\mathrm{H}$-bond was formed. ${ }^{30}$ The main characteristic peaks of $\mathrm{ChCl}$ and PEG could be observed in the FT-IR spectrum of DES, which identified that functional groups of the reactant were stable when the reaction was proceeding. To further confirm the interactions between $\mathrm{ChCl}$ and PEG, ${ }^{1} \mathrm{H}$ NMR of $\mathrm{ChCl}$, PEG and DES were obtained as shown in Fig. 1(b). The H peak (8.24 ppm) of the PEG and DES exhibited the same shift, which indicated that the charge density of the proton remained unchanged while the reaction was proceeding. Moreover, the $\mathrm{H}$ peak (5.594 ppm) of $\mathrm{ChCl}$ shifted to a lower value (5.53 ppm). This phenomenon suggested that the hydrogen bond of the DES was formed between $\mathrm{ChCl}$ and PEG. ${ }^{30}$ 


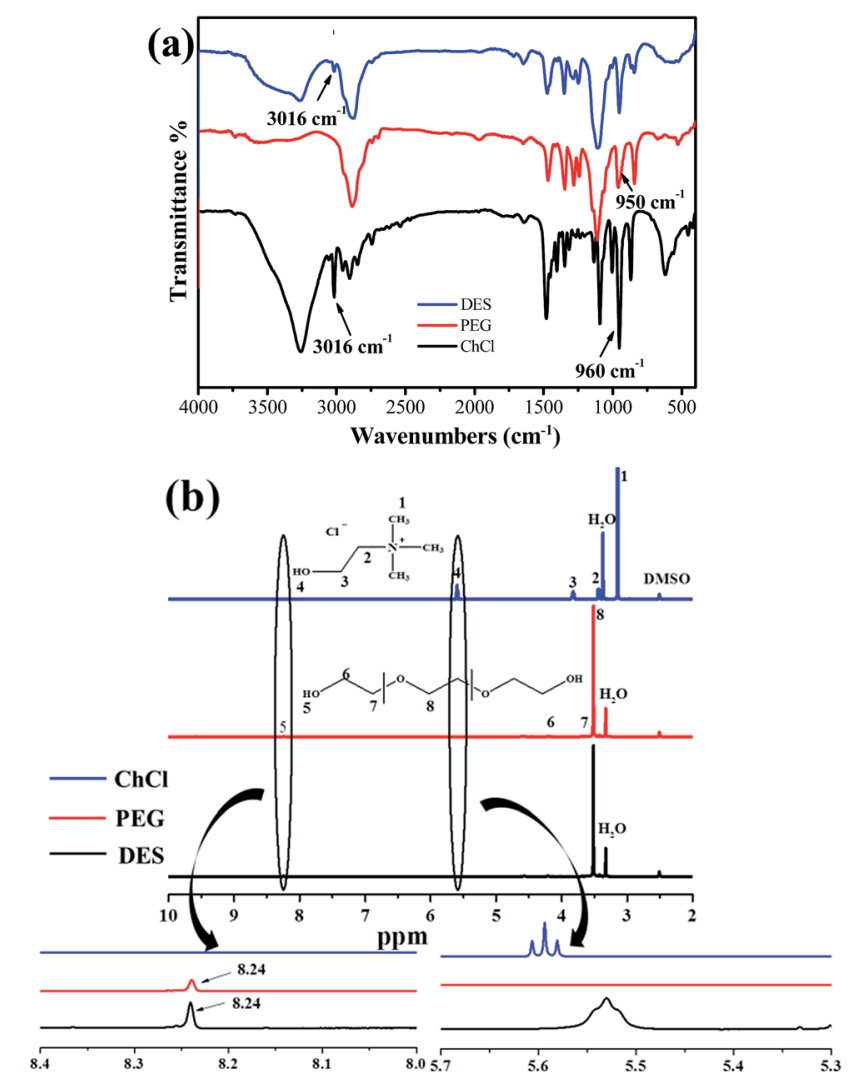

Fig. 1 (a) FT-IR spectra of DES, PEG and $\mathrm{ChCl}$. (b) ${ }^{1} \mathrm{H} \mathrm{NMR}$ of $\mathrm{ChCl}$, $P E G$ and DES (DMSO- $d_{6}$ as solvent).

\section{Phase behaviour}

The binodal curves determined at $298 \mathrm{~K}$ for the ABS composed of DES-salt $\left(\mathrm{NaH}_{2} \mathrm{PO}_{4}, \mathrm{Na}_{2} \mathrm{CO}_{3}\right.$ and $\left.\mathrm{Na}_{3} \mathrm{C}_{6} \mathrm{H}_{5} \mathrm{O}_{7}\right)$ are plotted in Fig. 2. The binodal data of the ABSs are summarized in detail in Table S3. $\dagger$ It is well known that closer the binodal curve of DESsalt to the origin of the coordinate axis, the stronger is the phase forming ability of the salts. The salts promoted the formation of ABS in the order: $\mathrm{Na}_{2} \mathrm{CO}_{3}>\mathrm{Na}_{3} \mathrm{C}_{6} \mathrm{H}_{5} \mathrm{O}_{7}>\mathrm{NaH}_{2} \mathrm{PO}_{4}$. Therefore, DES- $\mathrm{Na}_{2} \mathrm{CO}_{3} \mathrm{ABS}$ was chosen for the subsequent study.

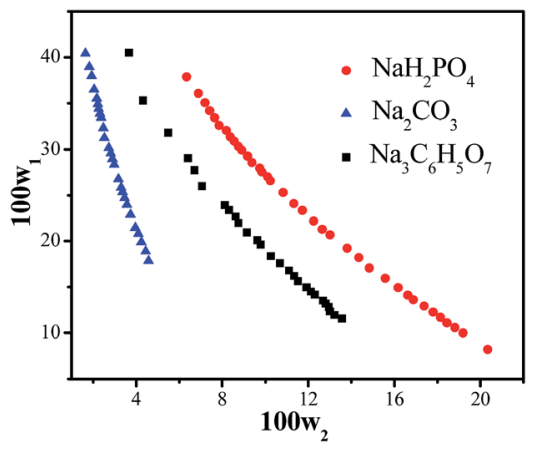

Fig. 2 Binodal curves for the DES + salt $\left(\mathrm{NaH}_{2} \mathrm{PO}_{4}, \mathrm{Na}_{2} \mathrm{CO}_{3}\right.$, $\left.\mathrm{Na}_{3} \mathrm{C}_{6} \mathrm{H}_{5} \mathrm{O}_{7}\right)+\mathrm{H}_{2} \mathrm{O}$ systems at $298 \mathrm{~K}$. ( $w_{1}$ : mass fraction of DES in the total system; $w_{2}$ : mass fraction of salt in the total system).

\section{Selection of extraction system}

The extraction efficiencies of the proteins for the three systems were investigated under the same conditions and the results are shown in Fig. 3. The results clearly indicated that $72.36-87.97 \%$ of the proteins could be extracted in the DES-rich phase by a single-step extraction procedure, and the extraction efficiency of the systems decreased in the order: $\mathrm{Na}_{2} \mathrm{CO}_{3}>\mathrm{Na}_{3} \mathrm{C}_{6} \mathrm{H}_{5} \mathrm{O}_{7}>$ $\mathrm{NaH}_{2} \mathrm{PO}_{4}$, which was similar to the order of phase-forming ability. Therefore, DES- $\mathrm{Na}_{2} \mathrm{CO}_{3}$ ABS was evaluated for the study of the extraction process. Moreover, the $\mathrm{pH}$ values of ABS were also measured and the results obtained are as follows: DES- $\mathrm{Na}_{2} \mathrm{CO}_{3} \mathrm{ABS}(\mathrm{pH}=12.83)$, DES- $\mathrm{Na}_{3} \mathrm{C}_{6} \mathrm{H}_{5} \mathrm{O}_{7} \mathrm{ABS}(\mathrm{pH}=$ 8.74) and DES- $\mathrm{NaH}_{2} \mathrm{PO}_{4} \mathrm{ABS}(\mathrm{pH}=3.44)$. Therefore, the $\mathrm{pH}$ also played a significant role in the extraction procedure.

For convenient and rapid screening of the extraction ability of DES- $\mathrm{Na}_{2} \mathrm{CO}_{3} \mathrm{ABS}$, bovine serum albumin and papain were chosen as representative examples for carrying out the ABS extraction method. The concentration of proteins, DES and $\mathrm{Na}_{2} \mathrm{CO}_{3}$ as well as the temperature and $\mathrm{pH}$ values related to extraction efficiency were considered. All extraction efficiencies were calculated in the same manner as described in the UV-vis method.

\section{Effect of the concentration of protein}

To investigate the concentration of protein on the influence of extraction efficiency, DES $\left(0.64 \mathrm{~g} \mathrm{~mL}^{-1}\right)-\mathrm{Na}_{2} \mathrm{CO}_{3}\left(0.12 \mathrm{~g} \mathrm{~mL}^{-1}\right)$ ABS was adopted and the results are illustrated in Fig. 4a. It was clear that the extraction efficiency increased with the increasing concentration of bovine serum albumin solution between $0.012 \mathrm{~g} \mathrm{~L}^{-1}$ and $0.03 \mathrm{~g} \mathrm{~L}^{-1}$; when the concentration of papain was higher than $0.03 \mathrm{~g} \mathrm{~L}^{-1}$, the extraction efficiency decreased gradually. In addition, the experimental results of papain extraction showed a similar tendency. The explanation for this phenomenon is that, when the concentration of protein was more than $0.03 \mathrm{~g} \mathrm{~mL}^{-1}$, the DES-rich top phase reached the saturated state and there was no more space for protein, which led to an increase in the amount of protein in the bottom phase. Therefore, the optimum concentration of both proteins was $0.03 \mathrm{~g} \mathrm{~L}^{-1}$.

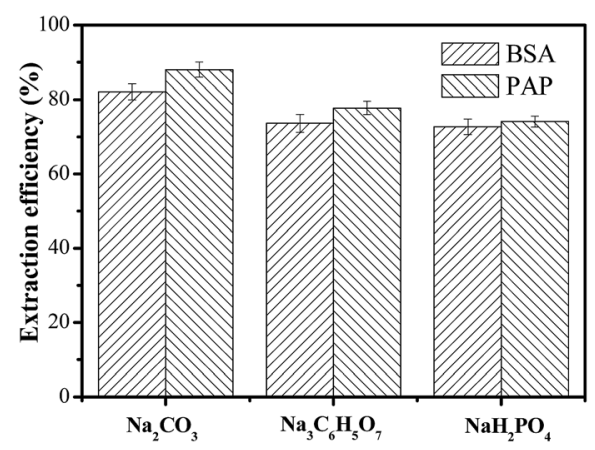

Fig. 3 Extraction efficiency of bovine serum albumin (BSA) and papain (PAP) in ABSs composed of: $C_{(D E S)}=0.64 \mathrm{~g} \mathrm{~mL}^{-1}, C_{\text {(salt) }}=0.12 \mathrm{~g} \mathrm{~mL}^{-1}$, $C_{\text {(protein) }}=0.03 \mathrm{~g} \mathrm{~L}^{-1}, T=298 \mathrm{~K}$, unadjusted $\mathrm{pH}$ values. 

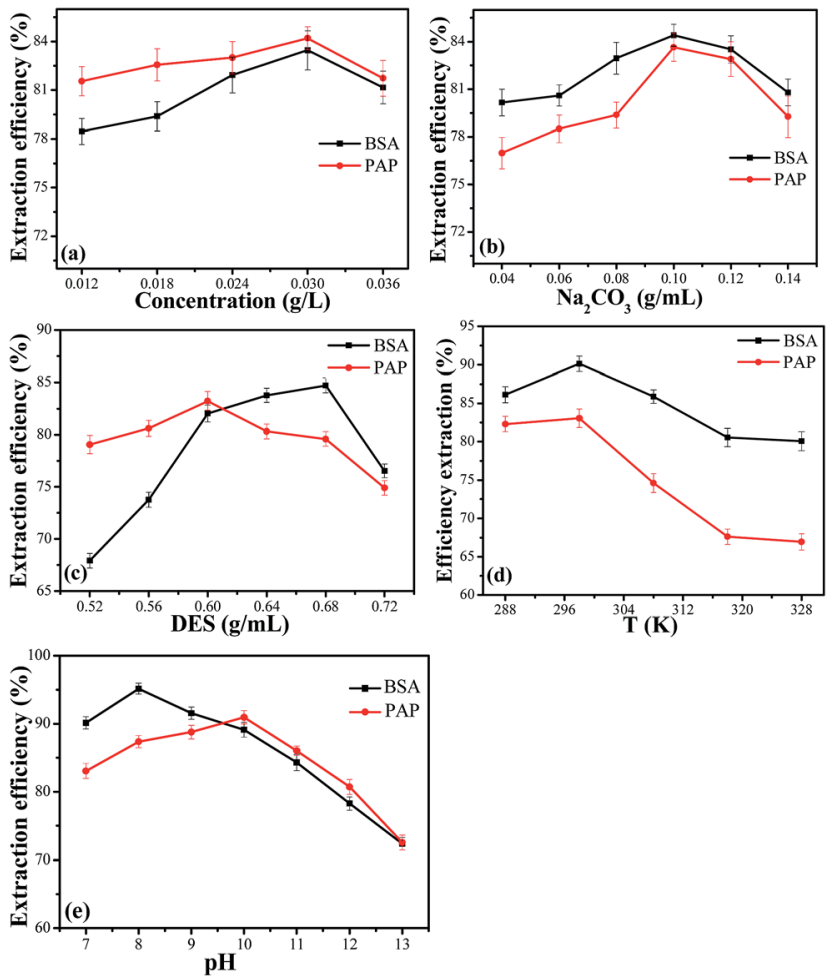

Fig. 4 Effect of the concentration of bovine serum albumin (BSA) and papain (PAP) (a), concentration of $\mathrm{Na}_{2} \mathrm{CO}_{3}$ (b), concentration of DES (c), temperature (d) and $\mathrm{pH}$ values (e) on the extraction efficiency in $\mathrm{DES}-\mathrm{Na}_{2} \mathrm{CO}_{3} \mathrm{ABS}$.

\section{Effect of the concentration of $\mathrm{Na}_{2} \mathrm{CO}_{3}$}

In order to discuss the effect of the concentration of $\mathrm{Na}_{2} \mathrm{CO}_{3}$ on the extraction efficiency, DES $\left(0.64 \mathrm{~g} \mathrm{~mL}^{-1}\right)-\mathrm{Na}_{2} \mathrm{CO}_{3}$ ABS was employed. As indicated in Fig. 4b, the extraction efficiency was affected as the salt concentration ranged from $0.04 \mathrm{~g} \mathrm{~mL}^{-1}$ to $0.14 \mathrm{~g} \mathrm{~mL}^{-1}$. With the increase in salt concentration, the hydrophobicity of the bottom phase increased. Therefore, the proteins were salted out from the bottom phase and transferred into the top phase. However, the extraction efficiency was decreased when the salt concentration reached $0.1 \mathrm{~g} \mathrm{~mL}^{-1}$. A further increase in salt concentration resulted in a decrease in the water content of the top phase and the proteins were inclined to enter the bottom phase. Therefore, a salt concentration of $0.1 \mathrm{~g} \mathrm{~mL}^{-1}$ was selected to continue the next experiment.

\section{Effect of the concentration of DES}

As an example, the effect of the concentration of DES on protein extraction was studied. In addition, the results are illustrated in Fig. 4c. The extraction efficiency of bovine serum albumin increased when the concentration of DES varied from $0.52 \mathrm{~g} \mathrm{~mL}^{-1}$ to $0.68 \mathrm{~g} \mathrm{~mL}^{-1}$, and with a further increase in the concentration of DES, the extraction efficiency decreased. The explanation for the increase was that the DES and protein could form aggregates in the top phase, and hence, more bovine serum albumin molecules would be aggregated by more DES micelles. ${ }^{40}$ When the DES concentration was further increased, there would be no more space in the top phase, which led to a decrease in the extraction efficiency. The extraction efficiency of papain also had the same tendency. Therefore, a DES concentration of $0.68 \mathrm{~g} \mathrm{~mL}^{-1}$ for bovine serum albumin and $0.6 \mathrm{~g} \mathrm{~mL}^{-1}$ for papain were selected in the subsequent experiments.

\section{Effect of the temperature}

The influence of temperature on the extraction efficiency of bovine serum albumin and papain was also investigated. The line graph (Fig. 4d) shows that the extraction efficiency of bovine serum albumin and papain both increased clearly when the temperature was below $298 \mathrm{~K}$. However, the efficiency of both decreased gradually after reaching the peak value at $298 \mathrm{~K}$. The possible reason for this phenomenon was that the viscosity of DES decreased with the increase in temperature, which enhanced the diffusion ability of proteins. However, a continuous increase in temperature could inhibit the interaction between the amino acid residue and the surface water of protein, which was unfavourable for protein extraction. ${ }^{\mathbf{4 1}}$ Furthermore, as the temperature increased, the ABS tended to be homogeneous.

\section{Effect of pH}

The electrostatic interaction played an important role in the separation and purification of proteins. DES- $\mathrm{Na}_{2} \mathrm{CO}_{3} \mathrm{ABS}$ could not form two phases at a $\mathrm{pH}$ below 6.0. Therefore, the $\mathrm{pH}$ range of 7.0-13.0 was chosen in this study. As can be seen from Fig. 4e, the extraction efficiency of bovine serum albumin and papain increased with the increase in $\mathrm{pH}$ value and then decreased gradually. The charged state of proteins was influenced by the pH values. Therefore, it was suggested that electrostatic interactions between the charged groups in the protein and the DES was a significant factor for the extraction of proteins. The obtained maximum extraction efficiency of bovine serum albumin was $95.16 \%$, which was higher than other ABSs; the comparative results are listed in Table 1.

After the single factor experiments were completed, the optimum extraction conditions were as follows: DES $\left(0.68 \mathrm{~g} \mathrm{~mL}^{-1}\right) /$ $\mathrm{Na}_{2} \mathrm{CO}_{3}\left(0.1 \mathrm{~g} \mathrm{~mL}^{-1}\right) /$ bovine serum albumin $\left(0.03 \mathrm{~g} \mathrm{~L}^{-1}\right) / 298 \mathrm{~K} /$

Table 1 Comparison of the BSA extraction performance of ABSs with that of other reported systems ${ }^{a}$

\begin{tabular}{|c|c|c|c|}
\hline ABSs & Target & $E(\%)$ & Reference \\
\hline$[\mathrm{Omim}][\mathrm{Br}]-\mathrm{K}_{2} \mathrm{HPO}_{4}$ & BSA & 90.5 & 42 \\
\hline$[\mathrm{DMEA}][\mathrm{Pr}]-\mathrm{K}_{2} \mathrm{HPO}_{4}$ & BSA & 99.5 & 43 \\
\hline Choline-like IL- $\mathrm{K}_{2} \mathrm{HPO}_{4}$ & BSA & $92.03-100.03 \%$ & 44 \\
\hline Guanidinium $\mathrm{IL}-\mathrm{K}_{2} \mathrm{CO}_{3}$ & BSA & 97.05 & 45 \\
\hline DES- ${ }_{2} \mathrm{HPO}_{4}$ & BSA & 98.16 & 40 \\
\hline DES- $\mathrm{Na}_{2} \mathrm{CO}_{3}$ & BSA & 95.16 & This study \\
\hline
\end{tabular}

${ }^{a}$ ABSs: aqueous biphasic systems; E: extraction efficiency; IL: ionic liquid; DES: deep eutectic solution; BSA: bovine serum albumin. 
$\mathrm{pH}=8$ and DES $\left(0.6 \mathrm{~g} \mathrm{~mL}^{-1}\right) / \mathrm{Na}_{2} \mathrm{CO}_{3}\left(0.1 \mathrm{~g} \mathrm{~mL}^{-1}\right) /$ papain $\left(0.03 \mathrm{~g} \mathrm{~L}^{-1}\right) / 298 \mathrm{~K} / \mathrm{pH}=10$.

\section{Back-extraction of protein}

It is well known that back-extraction is of great importance for the application of the prepared ABSs. Taking into account the optimal condition, the ABS consisted of DES $\left(0.68 \mathrm{~g} \mathrm{~mL}^{-1}\right) /$ $\mathrm{Na}_{2} \mathrm{CO}_{3}\left(0.1 \mathrm{~g} \mathrm{~mL}^{-1}\right)$, which was favorable for back-extraction. DES phase $(1 \mathrm{~mL})$, after extraction, was added into new centrifuge tubes. Then, different concentrations of $\left(\mathrm{NH}_{4}\right)_{2} \mathrm{SO}_{4}$ and $0.45 \mathrm{~mL}$ ethanol were added to form new ABSs. The results for back-extraction efficiency using the new ABSs are listed in Table 2. The back-extraction efficiency increased at first and decreased later with the increase in $\left(\mathrm{NH}_{4}\right)_{2} \mathrm{SO}_{4}$ concentration. Bovine serum albumin weighing $34.35 \%$ could be re-extracted into the salt-rich phase when the concentration of $\left(\mathrm{NH}_{4}\right)_{2} \mathrm{SO}_{4}$ was $0.16 \mathrm{~g} \mathrm{~mL}^{-1}$.

\section{UV-vis spectroscopy and fluorescence spectra}

In order to examine the confirmation of protein before and after extraction, UV-vis and fluorescence spectra were investigated. Fig. 5a illustrates the UV-vis spectra of bovine serum albumin in pure water and in DES-rich phase after extraction. It is clear that the curves appeared similar in shape and the maximum absorption peak after extraction still appeared at $278 \mathrm{~nm}$. Fig. 5b shows the fluorescence emission spectra for bovine serum albumin in the presence of DES at $\lambda_{\text {ex }}=287 \mathrm{~nm}$; the characteristic peaks of bovine serum albumin in water and in DES-rich solution both appeared at $344 \mathrm{~nm}$. In addition, the excitation spectra at $\lambda_{\mathrm{em}}=344 \mathrm{~nm}$ followed the similar trend. This indicated that there were no chemical interactions between the bovine serum albumin and DES in the extraction process. Hence, we tentatively concluded that the DES-based ABSs provided a gentle environment for bovine serum albumin.

Table 2 Back-extraction efficiency of ABSs with different salt concentrations

\begin{tabular}{llllll}
\hline$C / \mathrm{g} \mathrm{mL}$ & 0.12 & 0.14 & 0.16 & 0.18 & 0.2 \\
$V_{\mathrm{t}} / \mathrm{mL}$ & 1.3 & 1.2 & 1.1 & 1 & 1 \\
$E \%$ & 20.70 & 26.85 & 34.35 & 27.60 & 21.30
\end{tabular}
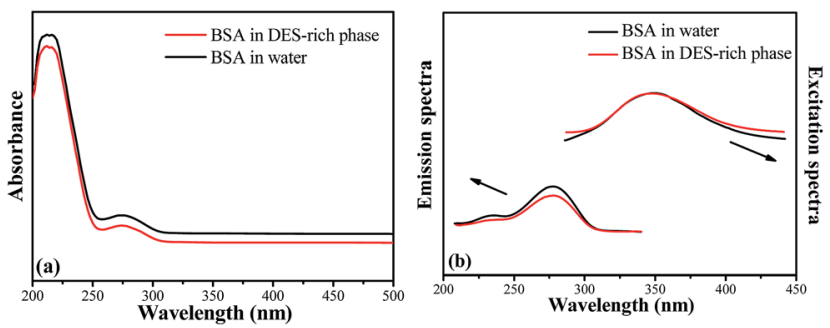

Fig. 5 UV-vis spectra (a) and fluorescence spectra (b) of bovine serum albumin (BSA) before and after extraction.

\section{Circular dichroism (CD) spectra}

Circular dichroism (CD) is a valuable technique for defining the secondary structure of proteins because many conformational motifs of protein exhibit characteristic far-ultraviolet $\mathrm{CD}$ spectra. Bovine serum albumin solution of $0.3 \mathrm{mg} \mathrm{mL}^{-1}$ has been selected to perform the experiment and the scanned range of CD spectra was 195-250 $\mathrm{nm}$. The response time was $1 \mathrm{~s}$ and the optical path was $10 \mathrm{~mm}$. The $\alpha$-helix structure of the protein showed a positive ellipticity at $192 \mathrm{~nm}$ and a double-negative ellipticity at 208 and $222 \mathrm{~nm}$. Fig. 6 shows that the CD spectra of bovine serum albumin in DES phase were similar to that in aqueous solution. In general, the results indicated that the secondary structures of bovine serum albumin in our study did not change after extraction.

\section{Transmission electron microscope}

Transmission electron microscope (TEM) was a significant tool to detect the microstructure of the sample. In this study, TEM was used to characterize the morphology of BSA before and after extraction. Fig. 7a and b show the morphology of BSA particles before and after extraction. The images displayed that the DES aggregate-protein complex had a size of almost $200 \mathrm{~nm}$ when the BSA was extracted in the top phase. It was clear that proteinDES aggregates were formed after extraction. That is to say, the protein and DES-aggregates were attracted to each other. It can be inferred that the aggregation was the driving force in the process of protein extraction by the DES-based ABS.

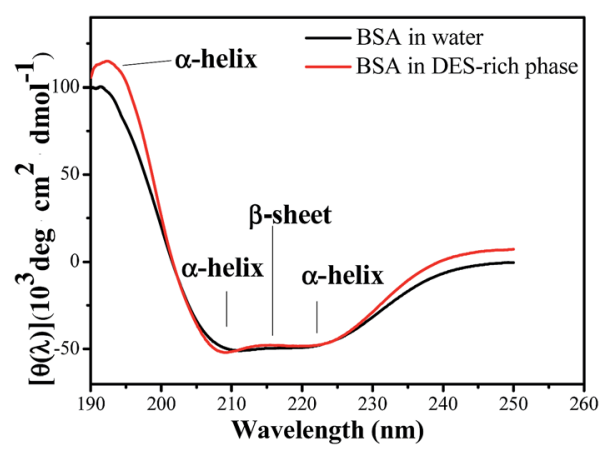

Fig. 6 CD spectra of bovine serum albumin (BSA) before and after extraction.

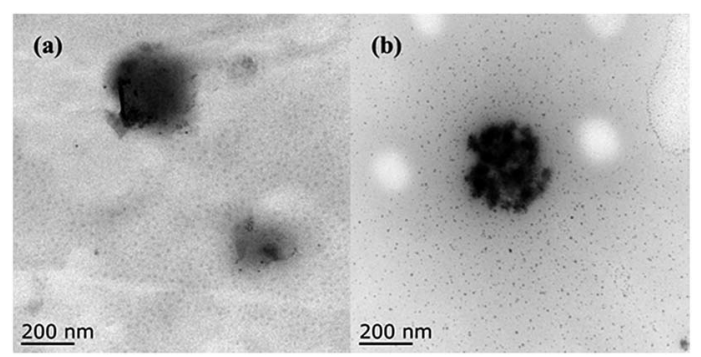

Fig. 7 TEM images of the aggregates for BSA (5.0 $\mathrm{mg} \mathrm{mL}^{-1}$ ) and DES $\left(0.5 \mathrm{~g} \mathrm{~mL}^{-1}\right)+\mathrm{BSA}\left(5.0 \mathrm{mg} \mathrm{mL}^{-1}\right)$. (a) BSA and (b) DES + BSA. 


\section{Conclusions}

Choline chloride-polyethylene glycol, defined as DES, was prepared, characterized and established as aqueous biphasic systems (ABSs) using three different salts $\left(\mathrm{NaH}_{2} \mathrm{PO}_{4}, \mathrm{Na}_{2} \mathrm{CO}_{3}\right.$ and $\mathrm{Na}_{3} \mathrm{C}_{6} \mathrm{H}_{5} \mathrm{O}_{7}$, respectively). DES- $\mathrm{Na}_{2} \mathrm{CO}_{3} \mathrm{ABS}$ was used to extract bovine serum albumin and papain through single-factor experiments and the back-extraction experiment was carried out using a certain amount of ethanol. Mechanism study suggested that no degeneration of protein was observed during the extracted process and the aggregation phenomenon played a significant role in the separation process. The advantage of DES such as being green, biodegradable and having no reaction with protein combined with the high extraction efficiency of bovine serum albumin (95.16\%) and papain (90.95\%) collectively highlighted the advantages of the designed method of DES-based ABSs for the extraction of protein. Moreover, the systems would have potential applications in bio-separation.

\section{Conflicts of interest}

There are no conflicts to declare.

\section{Acknowledgements}

This study was financially supported by the National Nature Science Foundation of China (No. 21506083, 21376111, 21576122), Scientific Research Foundation of Jiangsu University for the Senior Personnel (No. 15JDG176), Doctoral Innovation Fund of Jiangsu Province (KYLX16_0915).

\section{Notes and references}

1 P. A. Albertsson, Partition of cell particles and macromolecules, J. Wiley, 1960.

2 E. V. Capela, M. V. Quental, P. Domingues, J. A. P. Coutinho and M. G. Freire, Green Chem., 2017, 19, 1850.

3 C. E. de Araujo Padilha, P. V. Fortunato Dantas, F. C. Sousa Junior, S. D. Oliveira Junior, C. d. C. Nogueira, D. F. de Santana Souza, J. A. de Oliveira, G. R. de Macedo and E. S. dos Santos, Sep. Purif. Technol., 2017, 176, 306.

4 S. Noshadi and R. Sadeghi, J. Phys. Chem. B, 2017, 121, 2650.

5 M. H. Hadzir, S. Abbasiliasi, A. B. Ariff, S. B. Yusoff, H. S. Ng and J. S. Tan, RSC Adv., 2016, 6, 82571.

6 N. K. Subbaiyan, S. Cambre, A. N. G. Parra-Vasquez, E. H. Haroz, S. K. Doorn and J. G. Duque, ACS Nano, 2014, 8, 1619.

7 J. A. Fagan, C. Y. Khripin, C. A. S. Batista, J. R. Simpson, E. H. Haroz, A. R. H. Walker and M. Zheng, Adv. Mater., 2014, 26, 2800.

8 G. Ao, C. Y. Khripin and M. Zheng, J. Am. Chem. Soc., 2014, 136, 10383.

9 J. Flieger and A. Czajkowska-Zelazko, Food Chem., 2015, 166, 150.

10 J. F. B. Pereira, A. Magri, M. V. Quental, M. Gonzalez-Miquel, M. G. Freire and J. A. P. Coutinho, ACS Sustainable Chem. Eng., 2016, 4, 1512.
11 Y. Lu, H. Yao, C. Li, J. Han, Z. Tan and Y. Yan, Food Chem., 2016, 192, 163.

12 S. Shahriari, L. C. Tome, J. M. M. Araujo, L. P. N. Rebelo, J. A. P. Coutinho, I. M. Marrucho and M. G. Freire, $R S C$ Adv., 2013, 3, 1835.

13 T. Yao and S. Yao, J. Chromatogr. A, 2017, 1481, 12.

14 Y. B. Xie, H. B. Xing, Q. W. Yang, Z. B. Bao, B. G. Su and Q. L. Ren, ACS Sustainable Chem. Eng., 2015, 3, 3365.

15 Z. J. Tan, F. F. Li, C. C. Zhao, Y. B. Teng and Y. F. Liu, Sep. Purif. Technol., 2017, 172, 382.

16 C. P. Li, Z. Li, A. L. Wang, J. M. Yin, J. Wang, H. X. Li and Q. S. Liu, RSC Adv., 2013, 3, 6356.

17 H. M. Zhang, Y. Z. Wang, Y. G. Zhou, K. J. Xu, N. Li, Q. Wen and Q. Yang, Talanta, 2017, 170, 266.

18 Q. Zeng, Y. Wang, Y. H. Huang, X. Q. Ding, J. Chen and K. J. Xu, Analyst, 2014, 139, 2565.

19 H. M. Zhang, Y. Z. Wang, K. J. Xu, N. Li, Q. Wen, Q. Yang and Y. G. Zhou, Anal. Methods, 2016, 8, 8196.

20 K. E. Gutowski, G. A. Broker, H. D. Willauer, J. G. Huddleston, R. P. Swatloski, J. D. Holbrey and R. D. Rogers, J. Am. Chem. Soc., 2003, 125, 6632.

21 N. Gathergood, M. T. Garcia and P. J. Scammells, Green Chem., 2004, 6, 166.

22 J. R. Harjani, R. D. Singer, M. T. Garciac and P. J. Scammells, Green Chem., 2009, 11, 83.

23 J. R. Harjani, J. Farrell, M. T. Garcia, R. D. Singer and P. J. Scammells, Green Chem., 2009, 11, 821.

24 M. Zhang, W. S. Zhu, H. M. Li, S. H. Xun, W. J. Ding, J. J. Liu, Z. Zhao and Q. Wang, Chem. Eng. J., 2014, 243, 386.

25 W. H. Yao, H. Y. Wang, G. K. Cui, Z. Y. Li, A. L. Zhu, S. J. Zhang and J. J. Wang, Angew. Chem., Int. Ed., 2016, 55, 7934.

26 A. P. Abbott, G. Capper, D. L. Davies, R. K. Rasheed and V. Tambyrajah, Chem. Commun., 2003, 9, 70.

27 A. P. Abbott, D. Boothby, G. Capper, D. L. Davies and R. K. Rasheed, J. Am. Chem. Soc., 2004, 126, 9142.

28 N. Lopez-Salas, D. Carriazo, M. C. Gutierrez, M. L. Ferrer, C. O. Ania, F. Rubio, A. Tamayo, J. L. G. Fierro and F. del Monte, J. Mater. Chem. A, 2016, 4, 9146.

29 T. J. Trivedi, J. H. Lee, H. J. Lee, Y. K. Jeong and J. W. Choi, Green Chem., 2016, 18, 2834.

30 W. S. Zhu, C. Wang, H. P. Li, P. W. Wu, S. H. Xun, W. Jiang, Z. G. Chen, Z. Zhao and H. M. Li, Green Chem., 2015, 17, 2464.

31 W. Jiang, H. P. Li, C. Wang, W. Liu, T. Guo, H. Liu, W. S. Zhu and H. M. Li, Energy Fuels, 2016, 30, 8164.

32 H. P. Li, Y. H. Chang, W. S. Zhu, C. W. Wang, C. Wang, S. Yin, M. Zhang and H. M. Li, Phys. Chem. Chem. Phys., 2015, 17, 28729.

33 K. D. Vigier, G. Chatel and F. Jerome, Chemcatchem, 2015, 7, 1250.

34 L. Gu, W. Huang, S. K. Tang, S. J. Tian and X. W. Zhang, Chem. Eng. J., 2015, 259, 647.

35 M. C. Ali, Q. W. Yang, A. A. Fine, W. B. Jin, Z. G. Zhang, H. B. Xing and Q. L. Ren, Green Chem., 2016, 18, 157.

36 Y. Zhang, Z. Y. Li, H. Y. Wang, X. P. Xuan and J. J. Wang, Sep. Purif. Technol., 2016, 163, 310. 
37 K. J. Xu, Y. Z. Wang, Y. Li, Y. Lin, H. M. Zhang and Y. G. Zhou, Anal. Chim. Acta, 2016, 946, 64.

38 H. Chen, Q. Y. Ye, X. L. He, J. J. Ding, Y. Z. Zhang, J. F. Han, J. Liu, C. Liao, J. Mei and W. M. Lau, Green Chem., 2014, 16, 3841.

39 M. H. Chakrabarti, N. S. A. Manan, N. P. Brandon, R. C. Maher, F. S. Mjalli, I. M. AlNashef, S. A. Hajimolana, M. A. Hashim, M. A. Hussain and D. Nir, Chem. Eng. J., 2015, 274, 213.

40 K. J. Xu, Y. Z. Wang, Y. H. Huang, N. Li and Q. Wen, Anal. Chim. Acta, 2015, 864, 9.
41 A. Chakraborty and K. Sen, J. Chromatogr. A, 2016, 1433, 41. 42 X. Lin, Y. Z. Wang, Q. Zeng, X. Q. Ding and J. Chen, Analyst, 2013, 138, 6445.

43 J. Chen, Y. Z. Wang, Q. Zeng, X. Q. Ding and Y. Z. Huang, Anal. Methods, 2014, 6, 4067.

44 S. Y. Huang, Y. Z. Wang, Y. G. Zhou, L. Li, Q. Zeng and X. Q. Ding, Anal. Methods, 2013, 5, 3395.

45 X. Q. Ding, Y. Wang, Q. Zeng, J. Chen, Y. H. Huang and K. J. Xu, Anal. Chim. Acta, 2014, 815, 22. 